\title{
Synthesis and application of L-serine derivative ligands in Diels-Alder reaction between $C P D$ and methyl acrylate
}

Carlos A. D. Sousa, ${ }^{a}$ José E. Rodríguez-Borges ${ }^{b}$ and Cristina Freire ${ }^{a^{*}}$

a REQUIMTE, Departamento de Química e Bioquímica, Faculdade de Ciências da Universidade do Porto, Rua do Campo Alegre, 4169-007 Porto, Portugal

b Centro de Investigação em Química, Departamento de Química e Bioquímica, Faculdade de Ciências da Universidade do Porto, Rua do Campo Alegre, 4169007 Porto, Portugal

carlos.sousa@fc.up.pt

\begin{abstract}
New L-serine derivative ligands were prepared and tested as co-catalyst in the DielsAlder reactions between cyclopentadiene (CPD) and methyl acrylate in the presence of several Lewis acids. The catalytic potential of the in situ formed complexes was evaluated based on the reaction yield. Bidentate serine ligands showed good ability to coordinate medium strength Lewis acids, thus boosting their catalytic activity. The synthesis of the L-serine ligands proved to be highly efficient and straightforward. Silylated serines were also prepared for posterior grafting onto inorganic materials for application in heterogeneous catalysis.
\end{abstract}




\section{Introduction}

The synthesis of bicyclic compounds has detained large significance due to their use as synthetic intermediates in the preparation of a vast variety of compounds of chemical, biological, and pharmaceutical interest.[1-2] The most efficient and widely used method for the preparation of bicyclic compounds is the Diels-Alder reaction. Generally, activation by an electron-withdrawing group and a Lewis acid is required in order to achieve good conversion rates.

The acid catalyzed Diels-Alder reactions, namely between cyclopentadiene (CPD) and acrylates, is well documented,[1,3-15] the most important used Lewis acids being $\mathrm{Al}(\mathrm{III}), \mathrm{Fe}$ (III) or boron complexes. The use of such strong acids is needed because ester dienophiles (as acrylate ones) are not very reactive.[15-16] Depending on the reactions, the solvent used is also a factor to consider regarding both the Lewis acid solubility and the reaction media's polarity, the most common being dichloromethane.

In this work, we studied the use of moderate strength Lewis acids as catalysts for Diels-Alder reaction between CPD (1) and methyl acrylate (2) in dichloromethane (scheme 1), by complexing insoluble metal ions with novel L-serine derivative ligands, as alternative of the usual strong Lewis acids.

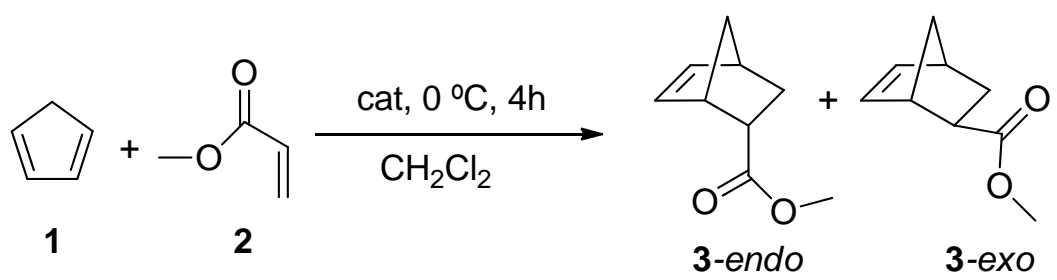

Scheme 1. Lewis acid catalyzed Diels-Alder reaction between CPD (1) and methyl acrylate (2).

\section{Results and discussion}

The work started with the study of several Lewis acids tested as catalysts in the DielsAlder reaction between CPD (1) and methyl acrylate (2) using dichloromethane as solvent; the results are summarized in table 1, as well as the reaction conditions.

Table 1. Results of the Diels-alder reaction between 1 and 2, yield and endo/exo ratio of adduct 3 .

\begin{tabular}{|c|c|c|c|c|}
\hline entry & catalyst & $\begin{array}{c}\text { reaction } \\
\text { time } / \mathbf{h}\end{array}$ & $\boldsymbol{\eta} / \%$ & $\begin{array}{c}\text { endo/exo } \\
\text { ratio }^{c}\end{array}$ \\
\hline 1 & - & & - & - \\
\hline 2 & $\mathrm{AlCl}_{3}$ & \multirow{2}{*}{4} & 87 & $95 / 5$ \\
\cline { 1 - 2 } \cline { 5 - 5 } & $\mathrm{AlMe}_{3}$ & & 70 & $93 / 7$ \\
\hline
\end{tabular}




\begin{tabular}{|c|c|c|c|c|}
\hline 4 & $\mathrm{FeCl}_{3}$ & & 75 & $95 / 5$ \\
\hline 5 & $\mathrm{TiCl}_{4}$ & & 80 & $94 / 6$ \\
\hline 6 & $\mathrm{SnCl}_{4}$ & & 67 & $94 / 6$ \\
\hline 7 & $\mathrm{Cu}(\mathrm{OTf})_{2}$ & & 35 & $98 / 2$ \\
\hline 8 & $\mathrm{ZnI}_{2}$ & & 11 & $94 / 6$ \\
\hline 9 & $\mathrm{Cu}(\mathrm{OTf})_{2}{ }^{a}$ & \multirow{2}{*}{20} & 38 & $85 / 15$ \\
\hline 10 & $\mathrm{ZnI}_{2}{ }^{a}$ & & 16 & $92 / 8$ \\
\hline 11 & $\mathrm{Cu}(\mathrm{OTf})_{2}{ }^{b}$ & 2 & 32 & $94 / 6$ \\
\hline 12 & $\mathrm{AlCl}_{3}$ & 20 & 53 & $91 / 9$ \\
\hline
\end{tabular}

The reactions were performed with $10 \%$ of catalyst, at $0{ }^{\circ} \mathrm{C}$ in dichloromethane, except in the mentioned cases. $a-0{ }^{\circ} \mathrm{C}$ to room temp.; $b-30 \%$ of catalyst; $c$-measured by ${ }^{1} \mathrm{H}-\mathrm{NMR}$;

As expected, in the absence of catalyst the reaction did not take place (entry 1). It is noteworthy the correlation observed between the Lewis acid strength and the yield of the reaction: the best results were achieved when the stronger Lewis acids $\mathrm{AlCl}_{3}, \mathrm{FeCl}_{3}$ and $\mathrm{TiCl}_{4}$ were employed (entries 2, 4 and 5, respectively). On comparison to $\mathrm{AlCl}_{3}$, a slight decrease in the reaction yield was observed when $\mathrm{AlMe}_{3}$ was used (entry 3). $\mathrm{SnCl}_{4}$ originated a lower yield than the previous mentioned strong Lewis acids (entry 6). For $\mathrm{Cu}(\mathrm{OTf})_{2}$ and $\mathrm{ZnI}_{2}$, which are moderate Lewis acids, the yields were quite low (entries 7,8); nevertheless, their poor solubility in the solvent used (dichloromethane) may also explain these results. The increasing of the reaction time (entries 9, 10) and of the amount of catalyst employed (entry 11) did not significantly changed the results in terms of yield. In fact, similar results were observed in a previous work comprising the catalytic cycloaddition reaction between CPD and methyl glyoxylate oxime.[17] It is possible, however, that the increasing of reaction time when strong acids were used decreased de yield of Diels-Alder reactions, probably due to decomposition of the final adduct (entry 12).[17-18]

Considering this, we synthesized new L-serine derivative ligands as inexpensive ligands for application on the Diels-Alder reactions. Serine has two major advantages for this purpose: is cheap and readily available and has three functional groups that may be easily functionalized, thus allowing chemical and structural design. In fact, serine was earlier used for other purposes as evaluation as ligand for complex formation with $\mathrm{Cd}(\mathrm{II})$, complexation with $\mathrm{Cu}$ (II) for antibacterial studies and used as recyclable catalyst for asymmetric aldol reactions.[19-21] In this work, L-serine derivative ligands were designed and used to coordinate the Lewis acids, in order to form in situ metal 
complexes that would be more soluble in dichloromethane than the original Lewis acids. In this context, only $\mathrm{Cu}(\mathrm{II})$ and $\mathrm{Zn}$ (II) salts $\left(\mathrm{Cu}(\mathrm{OTf})_{2}\right.$ and $\mathrm{ZnI}_{2}$ ) were considered in the catalytic reaction. In fact, complexes of $\mathrm{Zn}(\mathrm{II})$ and $\mathrm{Cu}(\mathrm{II})$ are widely used as Lewis acids in Diels-Alder reactions.[1]

The chemical structures of the prepared L-serine derivative ligands 4-14 either from 8 or 9 (commercially available) are depicted in scheme 2. Ligand 4 was effectively obtained by protecting de amine group of serine 8 with Boc; ligands 5-7 were prepared in excellent yields by reacting the respective amine with serine 9 in the presence of DIPEA and TBTU. After removing the Fmoc group from serines 6/7, the resultant amines, as well as 8, were efficiently silylated with 3-(triethylsilyl)propyl isocyanate, affording serines 12-14.

The Diels-Alder reaction represented in scheme 1 was then tested in the presence of the ligands 4-14 and the results are summarized in table 2. The reaction conditions were those represented in scheme 1, except in the indicated cases.

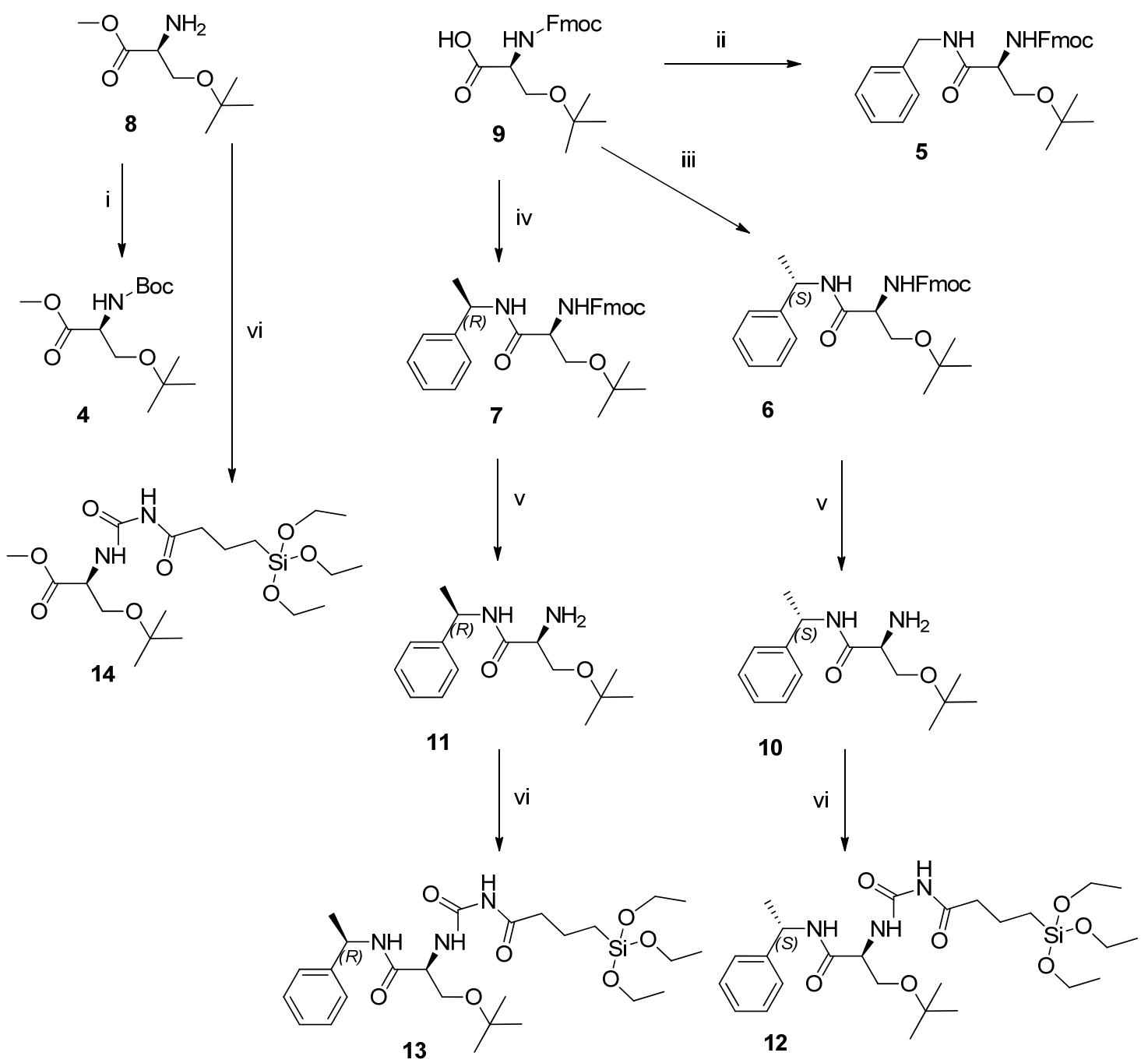

Scheme 2. L-serine derivative ligands used in the Diels-Alder reaction between 1 and 2. Reagents and conditions: $i$ - $\mathrm{Boc}_{2} \mathrm{O}, \mathrm{CH}_{2} \mathrm{Cl}_{2}$, r.t., $2 \mathrm{~h}$, ii- benzylamine, DIPEA, TBTU, $\mathrm{CH}_{2} \mathrm{Cl}_{2}$, r.t., 2 h, 99\%; iii- (S)-1-phenylethylamine, DIPEA, TBTU, $\mathrm{CH}_{2} \mathrm{Cl}_{2}$, r.t., 2 h, 
$100 \%$; iv- (R)-1-phenylethylamine, DIPEA, TBTU, $\mathrm{CH}_{2} \mathrm{Cl}_{2}$, r.t., 2 h, $100 \%$; vpiperidine, DMF, room temp. $2 \mathrm{~h}, 100 \%$; vi- $\mathrm{OCN}\left(\mathrm{CH}_{2}\right)_{3} \mathrm{Si}(\mathrm{OEt})_{3}, \mathrm{CH}_{2} \mathrm{Cl}_{2}$, reflux, overnight, $90-98 \%$.

Table 2. Results of the Diels-alder reaction between 1 and 2, yield, endo/exo ratio of adduct 3 and enantiomeric excess (e.e.).

\begin{tabular}{|c|c|c|c|c|c|c|}
\hline entry & catalyst & ligand & $\begin{array}{c}\text { reaction } \\
\text { time / h }\end{array}$ & $\eta / \%$ & $\begin{array}{c}\text { endo/exo } \\
\text { ratio }^{2}\end{array}$ & e.e. $/ \%^{3}$ \\
\hline 1 & $\mathrm{AlCl}_{3}$ & 8 & 4 & traces & - & - \\
\hline 2 & $\mathrm{FeCl}_{3}$ & 8 & 4 & $<5$ & - & - \\
\hline 3 & $\mathrm{Cu}(\mathrm{OTf})_{2}{ }^{1}$ & 8 & 20 & - & - & - \\
\hline 4 & $\mathrm{Cu}(\mathrm{OTf})_{2}{ }^{1}$ & 4 & 20 & $<5$ & - & - \\
\hline 5 & $\mathrm{Cu}(\mathrm{OTf})_{2}{ }^{1}$ & 9 & 20 & 31 & $90 / 10$ & $<1$ \\
\hline 6 & $\mathrm{Cu}(\mathrm{OTf})_{2}{ }^{1}$ & 5 & 20 & 59 & $82 / 18$ & $<1$ \\
\hline 7 & $\mathrm{ZnI}_{2}$ & 5 & 4 & 23 & $87 / 13$ & $<1$ \\
\hline 8 & $\mathrm{ZnI}_{2}{ }^{1}$ & 5 & 20 & 58 & $87 / 13$ & $<1$ \\
\hline 9 & $\mathrm{Cu}(\mathrm{OTf})_{2}{ }^{1}$ & 6 & 20 & 21 & $86 / 14$ & $12(R)$ \\
\hline 10 & $\mathrm{ZnI}_{2}{ }^{1}$ & 6 & 20 & 30 & $83 / 17$ & $24(R)$ \\
\hline 11 & $\mathrm{Cu}(\mathrm{OTf})_{2}{ }^{1}$ & 7 & 20 & 57 & $82 / 18$ & $8(R)$ \\
\hline 12 & $\mathrm{ZnI}_{2}{ }^{1}$ & 7 & 20 & 56 & $88 / 12$ & $10(R)$ \\
\hline 13 & $\mathrm{Cu}(\mathrm{OTf})_{2}{ }^{4}$ & 7 & 20 & 51 & $83 / 17$ & $8(R)$ \\
\hline 14 & $\mathrm{Cu}(\mathrm{OTf})_{2}{ }^{1}$ & 10 & 20 & 2 & $85 / 15$ & $18(R)$ \\
\hline 15 & $\mathrm{ZnI}_{2}{ }^{1}$ & 10 & 20 & 1 & $85 / 15$ & $16(R)$ \\
\hline 16 & $\mathrm{Cu}(\mathrm{OTf})_{2}^{1}$ & 11 & 20 & traces & - & - \\
\hline 17 & $\mathrm{ZnI}_{2}{ }^{1}$ & 11 & 20 & 2 & $81 / 19$ & $72(S)$ \\
\hline 18 & $\mathrm{Cu}(\mathrm{OTf})_{2}{ }^{1}$ & 13 & 20 & 12 & $84 / 16$ & $7(R)$ \\
\hline
\end{tabular}




\begin{tabular}{|c|c|c|c|c|c|c|}
\hline 19 & $\mathrm{ZnI}_{2}{ }^{1}$ & $\mathbf{1 3}$ & 20 & 13 & $85 / 15$ & $9(R)$ \\
\hline 20 & $\mathrm{Cu}(\mathrm{OTf})_{2}{ }^{1}$ & $\mathbf{1 2}$ & 20 & 14 & $85 / 15$ & $8(R)$ \\
\hline 21 & $\mathrm{ZnI}_{2}{ }^{1}$ & $\mathbf{1 2}$ & 20 & 18 & $85 / 15$ & $10(R)$ \\
\hline 22 & $\mathrm{Cu}(\mathrm{OTf})_{2}{ }^{1}$ & $\mathbf{1 4}$ & 20 & 58 & $82 / 18$ & $<1$ \\
\hline 23 & $\mathrm{ZnI}_{2}{ }^{1}$ & $\mathbf{1 4}$ & 20 & 58 & $87 / 13$ & $<1$ \\
\hline
\end{tabular}

The reactions were performed with $10 \%$ of both catalyst and ligand, at $0{ }^{\circ} \mathrm{C}$ in dichloromethane, except in the mentioned cases. $1-0{ }^{\circ} \mathrm{C}$ to room temp.; 2- measured by ${ }^{1} \mathrm{H}-\mathrm{NMR}$; 3- measured by chiral gaseous chromatography. The absolute configuration was determined by comparison with the $[\alpha]_{\mathrm{D}}$ value of an authentic sample;[15] 4- $10 \%$ of catalyst and $20 \%$ of ligand.

It is noteworthy that ligand $\mathbf{8}$ completely deactivated the metal catalyst (entries 1 , 2, 3), the strong catalytic effect of $\mathrm{AlCl}_{3}$ and $\mathrm{FeCl}_{3}$ (entries 2 and 4, table 1) being totally suppressed. This suggests that the cation coordinates to the basic amine group of $\mathbf{6}$ and the resulting complex is not sufficiently acidic to catalyze the Diels-Alder reaction. The Boc-protection of serine 8 led to serine ligand $\mathbf{4}$. The addition of $\mathbf{4}$ to a suspension of $\mathrm{Cu}(\mathrm{OTf})_{2}$ in dichloromethane did not result in a colored homogeneous solution, indicating that the complex 4-Cu was not formed. Consequently, the reaction yield was drastically decreased (entry 4, table 2 ) when compared with the use of $\mathrm{Cu}(\mathrm{OTf})_{2}$ alone (entry 9, table 1), as the acid character of the Lewis catalyst was compensated with the basic character of amide 4 . The same reaction was performed with serine $\mathbf{9}$ and $\mathrm{Cu}(\mathrm{OTf})_{2}$. Similarly, the 9-Cu complex was not formed, as indicated by the non homogenization of the solution. However, in this case the reaction yield was not significantly changed when compared with the use of $\mathrm{Cu}(\mathrm{OTf})_{2}$ alone (entry 5 , table 2 and entry 9 , table 1, respectively). This is in agreement with the acid character of 9.

The bidentate serine derivative ligands 5-7 were also tested as co-catalysts. The complete solubilization and coloring subsequent to the addition of ligands 5-7 to a suspension of the Lewis acids [yellow for $\mathrm{Zn}$ (II) and blue for $\mathrm{Cu}(\mathrm{II})$ ] points to a good metal to ligand complexation. By analyzing table 2, it is possible to verify that the use of ligands 5 significantly improved the reaction yield (when compared with the use of Lewis acid alone). We further studied the influence of steric effects near to the ligand binding atom on the catalytic performance, by comparing the performance of 5 (ligand with a benzylamine moiety) with $6[(S)$-phenylethylamine moiety] and $7[(R)$ phenylethylamine moiety]. The results clearly showed that the methyl group of the phenylethyl moiety slightly blocks the approximation of the CPD to the dienophilemetal-ligand complex when it is at $S$ configuration. On the other hand, the e.e. were slightly higher for 6 than for 7 (entries 9-12, table 2). No significant effect was observed when it is at $R$ configuration. The endo/exo ratio of $\mathbf{3}$ does not seem to significantly change with the used ligand. The use of metal:ligand molar ratio of 1:2 led to similar 
results to the usual 1:1 molar ratio (entries 11 and 13, table 2), suggesting that each metal ion coordinates to only one serine derivative ligand, contrarily to what occurs with $C_{2}$ symmetry ligands.[22] In fact, BOX ligands proved to be quite ineffective in this reaction, leading to very low yields and low e.e.; at the best of our knowledge, there are not reported any results concerning good e.e. obtained in the catalyzed Diels-Alder reaction between CPD and methyl acrylate.

By removing the Fmoc group of $\mathbf{6}$ and 7, we obtained the ligands $\mathbf{1 0}$ and 11, respectively, which were also tested as ligands. Similarly to what happened with ligand $\mathbf{8}$, the metal catalysts were deactivated, the yields of the reactions being too low (entries 14-17). The e.e obtained with 10 remained similar as the preceding serine $\mathbf{6}$. However, the e.e. obtained with the use of $\mathbf{1 1}$ was $72 \%$, the configuration of adduct $\mathbf{3}$ being $S$ (entry 14, table 2). Even though the reaction yields were negligible, this result proves that the configuration of the phenylethylamine moiety of the serine derivative ligand may influence the reaction enantioselectivity, which encouraged us to keep our investigation on these serine derivative ligands. We used the amino free group of serines 8, 10 and 11 to prepare the corresponding silylated serines in order to allow posterior grafting onto inorganic materials for posterior employment in heterogeneous catalysis. For this, we reacted the referred serines with 3-(triethylsilyl)propyl isocyanate, affording serines 14, 12 and 13, respectively. It is worthy to note that serine 14 led to yields similar to those obtained when serines 5 and 7 were used (entries 22 and 23, table 2); on the other hand, the e.e. were negligible, as expected. Silylated serines 12/13 showed low yields (entries 18-21), probably due to the existence of 3 coordination nitrogen atoms, which will encapsulate the metal ion thus difficulting the coordination of the catalytic complex to the dienophile. These observations confirm that the serine derivative ligands should be bidentated in order to effectively form complexes that efficiently catalyse the Diels Alder reaction between 2 and 3.

\section{Conclusions}

Bidentated L-serine based ligands showed good potential to be applied in DielsAlder reactions, particularly if coordinated to moderate-strength Lewis acids such as $\mathrm{Cu}(\mathrm{OTf})_{2}$ and $\mathrm{ZnI}_{2}$. This is an alternative to the usage of strong Lewis acids such as $\mathrm{AlCl}_{3}$ or $\mathrm{FeCl}_{3}$, as serine derivative ligands proved to allow good yields at mild conditions, are cheap and easy to prepare.

The results also anticipate that the change of the serine carboxylic residue by a chiral group may influence the stereochemistry of the Diels-Alder reaction, this subject being currently under study and development in our laboratory, as well as additional design optimization. The possibility of easily silylating of the referred serines with alkoxysilanes was also confirmed, which will allow posterior grafting onto inorganic materials for application in heterogeneous catalysis. 


\section{Materials and Methods}

\subsection{General notes}

All solvents were distilled and dried using standard methods. CPD was freshly bidistilled prior to use. All starting material and reagents were from commercial suppliers (Aldrich, Fluka, Bachem) and used without purification. Serine 6 was obtained by treatment of its commercial hydrochloride with triethylamine.

Flash column chromatography was performed on silica gel (60^, 230,240 mesh) and analytical thin-layer chromatography (TLC) on pre-coated silica gel 60 F254 plates using iodine vapor and/or UV light $(254 \mathrm{~nm})$ for visualization. Melting points were determined on an electrothermal melting point apparatus and are uncorrected. Optical rotations were measured on a conventional thermostated polarimeter using a sodium lamp.

\subsection{Experimental procedure for Diels-Alder reactions}

To a suspension of catalyst $(0.10 \mathrm{eq})$ in anhydrous dichloromethane $(10 \mathrm{ml})$ at the conditions referred in table 1 , methyl acrylate $(0.136 \mathrm{ml}, 1.50 \mathrm{mmol})$ and CPD $(0.125$ $\mathrm{ml}, 1.51 \mathrm{mmol})$ were added. The mixture was left to react with stirring under argon atmosphere. After the reaction period, the mixture was treated by either the methods: a) filtration through celite/silica with dichloromethane; b) extraction from water with dichloromethane, followed by drying with anhydrous $\mathrm{Na}_{2} \mathrm{SO}_{4}$. The solvent was eliminated at reduced pressure. Whenever necessary, methanol was added to the dry crude in order to polymerize unreacted CPD. The formed polymer was triturated, filtered off and washed with methanol. After evaporation of the volatiles, the crude was weight and analyzed by NMR in order to evaluate both the reaction yield and the endo/exo ratio.

For Diels-Alder reaction catalyzed by a serine-metal complex: to a suspension of catalyst $(0.10 \mathrm{eq})$ in anhydrous dichloromethane $(10 \mathrm{ml})$ at the conditions referred in table 2 , the ligand $(0.10 \mathrm{eq})$ was added and the mixture was left to react under argon atmosphere into an ice bath during $30 \mathrm{~min}$. After this period, methyl acrylate $(0.136 \mathrm{ml}$, $1.50 \mathrm{mmol})$ and CPD $(0.125 \mathrm{ml}, 1.51 \mathrm{mmol})$ were added, the subsequent procedure being similar to the previously described.

( \pm )-methyl bicyclo[2.2.1] hept-5-ene-2-endo-carboxylate (3-endo): ${ }^{1} \mathrm{H} \mathrm{NMR}(400 \mathrm{MHz}$, $\left.\mathrm{CDCl}_{3}\right): \delta=8.71(\mathrm{dd}, J=5.7,3.1 \mathrm{~Hz}, 1 \mathrm{H}, 5-\mathrm{H}), 5.95(\mathrm{dd}, J=5.7,2.8 \mathrm{~Hz}, 1 \mathrm{H}, 6-\mathrm{H})$, $3.65\left(\mathrm{~s}, 3 \mathrm{H}, \mathrm{OCH}_{3}\right), 3.20-3.24(\mathrm{~m}, 1 \mathrm{H}, 1-\mathrm{H}), 2.97(\mathrm{dt}, J=9.3,3.8 \mathrm{~Hz}, 1 \mathrm{H}, 2-\mathrm{H}), 2.90-$ 2.95 (m, 1H, 4-H), 1.93 (ddd, $J=12.0,9.3,3.7 \mathrm{~Hz}, 1 \mathrm{H}, 3-\mathrm{H}), 1.41-1.48$ (m, 1H, 3-H + $\left.7_{\text {syn }}-\mathrm{H}\right), 1.27-1.23\left(\mathrm{~m}, 1 \mathrm{H}, 7_{\text {anti }}-\mathrm{H}\right)$;

( \pm )-methyl bicyclo[2.2.1] hept-5-ene-2-exo-carboxylate (3-exo): ${ }^{1} \mathrm{H}$ NMR (400 MHz, $\left.\mathrm{CDCl}_{3}\right): \delta=6.16(\mathrm{dd}, J=5.6,2.9 \mathrm{~Hz}, 1 \mathrm{H}, 5-\mathrm{H}), 6.13(\mathrm{dd}, J=5.5,3.0 \mathrm{~Hz}, 1 \mathrm{H}, 6-\mathrm{H})$, $3.72\left(\mathrm{~s}, 3 \mathrm{H}, \mathrm{OCH}_{3}\right), 3.05-3.08(\mathrm{~m}, 1 \mathrm{H}, 4-\mathrm{H}), 2.23-2.28(\mathrm{~m}, 1 \mathrm{H}), 1.53-1.57(\mathrm{~m}, 1 \mathrm{H})$ (other signals are superimposed);

\subsection{Synthesis of L-serine derivative ligands}


(S)-methyl 3-(tert-butoxy)-2-((tert-butoxycarbonyl)amino)propanoate (4): A solution of $8(0.200 \mathrm{~g}, 0.945 \mathrm{mmol})$ and $\mathrm{Boc}_{2} \mathrm{O}(0.207 \mathrm{~g}, 0.948 \mathrm{mmol})$ in anhydrous dichloromethane $(5 \mathrm{ml})$, was stirred at room temperature under argon atmosphere overnight. $10 \mathrm{ml}$ of water was added and the organic phase was separated. The aqueous phase was extracted with dichloromethane $(3 \times 10 \mathrm{ml})$. The organic extracts were rinsed with brine, dried over anhydrous $\mathrm{Na}_{2} \mathrm{SO}_{4}$ and evaporated at reduced pressure, yielding a colorless oil that was purified by chromatographic column (eluent: Hex/AcOEt 1:1). Traces of $\mathrm{Boc}_{2} \mathrm{O}$ were eliminated by leaving the oil under high vacuum overnight. $\eta=$ $86 \%$.

${ }^{1} \mathrm{H}$ NMR (400 MHz, $\mathrm{CDCl}_{3}$ ): $\delta=5.35(\mathrm{~d}, J=8.4 \mathrm{~Hz}, 1 \mathrm{H}, \mathrm{NH}), 4.33-4.43(\mathrm{~m}, 1 \mathrm{H}, \mathrm{CH})$, $3.79\left(\mathrm{dd}, J=2.8,8.9 \mathrm{~Hz}, 1 \mathrm{H}, \mathrm{OC}_{\mathrm{H}} \mathrm{CH}_{\mathrm{b}}\right), 3.73\left(\mathrm{~s}, 3 \mathrm{H}, \mathrm{OCH}_{3}\right), 3.56(\mathrm{dd}, J=3.2,9.0 \mathrm{~Hz}$, $\left.1 \mathrm{H}, \mathrm{OCH}_{\mathrm{a}} \underline{\mathrm{CH}}_{\mathrm{b}}\right), 1.45\left(\mathrm{~s}, 9 \mathrm{H}, \mathrm{C}\left(\mathrm{CH}_{3}\right)_{3}\right), 1.13\left(\mathrm{~s}, 9 \mathrm{H}, \mathrm{C}\left(\mathrm{CH}_{3}\right)_{3}\right) ;{ }^{13} \mathrm{C}$ NMR (100 MHz, $\left.\mathrm{CDCl}_{3}\right): \delta=171.6(\mathrm{COO}), 155.7(\mathrm{HNCOO}), 79.9\left(\underline{\mathrm{C}}\left(\mathrm{CH}_{3}\right)_{3}\right), 73.4\left(\left(\underline{\mathrm{C}}\left(\mathrm{CH}_{3}\right)_{3}\right), 62.2\right.$ $\left.\left(\mathrm{OCH}_{2}\right), 54.4(\mathrm{CH}), 52.3\left(\mathrm{OCH}_{3}\right), 28.4\left(\mathrm{C}_{\left(\mathrm{CH}_{3}\right.}\right)_{3}\right), 27.4\left(\mathrm{C}\left(\underline{\mathrm{CH}}_{3}\right)_{3}\right)$; ESI-MS: calculated for $\left[\mathrm{C}_{13} \mathrm{H}_{25} \mathrm{NO}+\mathrm{H}\right]^{+}\left(\mathrm{M}+\mathrm{H}^{+}\right)$276.17, obtained 276.22;

Bidentated Serines (5-7): To a solution of $9(0.50 \mathrm{~g}, 1.3 \mathrm{mmol})$ in anhydrous dichloromethane $(25 \mathrm{ml})$, TBTU (0.63 g, $2.0 \mathrm{mmol})$, DIPEA $(0.34 \mathrm{ml}, 2.0 \mathrm{mmol})$ and the corresponding amine $(1.3 \mathrm{mmol})$ were added. The mixture was left to react at room temperature under argon atmosphere for $2 \mathrm{~h} .10 \mathrm{ml}$ of water was added and the organic phase was separated. The aqueous phase was extracted with dichloromethane $(3 \times 10$ $\mathrm{ml}$ ). The organic extracts were rinsed with brine, dried over anhydrous $\mathrm{Na}_{2} \mathrm{SO}_{4}$ and evaporated at reduced pressure, affording the expected serine derivative ligands 5, 6 or 7 with $99 \%$ yield. No further purifications were needed.

(S)-(9H-fluoren-9-yl)methyl (1-(benzylamino)-3-(tert-butoxy)-1-oxopropan-2yl)carbamate (5): ${ }^{1} \mathrm{H}$ NMR $\left(400 \mathrm{MHz}, \mathrm{CDCl}_{3}\right): \delta=7.79\left(\mathrm{~d}, J=7.5 \mathrm{~Hz}, 2 \mathrm{H}, \mathrm{H}_{\mathrm{ar}-}\right.$ Fluoren $), 7.62\left(\mathrm{~d}, J=7.4 \mathrm{~Hz}, 2 \mathrm{H}, \mathrm{H}_{\mathrm{ar}-F l u o r e n}\right), 7.39-7.45\left(\mathrm{~m}, 2 \mathrm{H}_{\mathrm{ar}}\right), 7.28-7.38\left(\mathrm{~m}, 7 \mathrm{H}_{\mathrm{ar}}\right)$, 6.91 (bs, 1H, NH), 5.79 (bs, 1H, NH), 4.47-4.57 (sl, 2H, $\left.\underline{\mathrm{H}}_{2} \mathrm{Ph}\right), 4.44$ (d, J=6.8 Hz, $\left.2 \mathrm{H}, \mathrm{COOC} \underline{H}_{2}\right), 4.28(\mathrm{sl}, 1 \mathrm{H}, \mathrm{COCH}), 4.24\left(\mathrm{t}, J=7.0 \mathrm{~Hz}, 1 \mathrm{H}, \mathrm{CH}_{\text {Fluoren }}\right), 3.87$ (dd, $J=$ 8.6, 3.7 Hz, 1H, OC$\left.\underline{H}_{\mathrm{a}} \mathrm{CH}_{\mathrm{b}}\right), 3.42\left(\mathrm{t}, J=8.0 \mathrm{~Hz}, 1 \mathrm{H}, \mathrm{OCH}_{\mathrm{a}} \underline{\mathrm{H}}_{\mathrm{b}}\right), 1.17\left(\mathrm{~s}, 9 \mathrm{H}, \mathrm{C}\left(\mathrm{CH}_{3}\right)_{3}\right)$; ${ }^{13} \mathrm{C} \mathrm{NMR}\left(100 \mathrm{MHz}, \mathrm{CDCl}_{3}\right): \delta=170.2$ (COO), 156.1 (HNCOO), 143.8 and $143.7(2 \times$ $\left.\mathrm{C}_{\text {Fluoren }}\right), 141.3\left(2 \times \mathrm{C}_{\text {Fluoren }}\right), 137.9\left(\mathrm{C}_{\text {ipso Ph }}\right), 128.7\left(2 \times \mathrm{C}_{\text {meta }} \mathrm{Ph}\right), 127.8\left(2 \times \mathrm{CH}_{\text {Fluoren }}\right)$, $127.6\left(2 \times \mathrm{C}_{\text {ortho } \mathrm{Ph}}\right), 127.5\left(\mathrm{C}_{\text {para }} \mathrm{Ph}\right), 127.1\left(2 \times \mathrm{CH}_{\text {Fluoren }}\right), 125.0$ and $125.1(2 \times$ $\left.\mathrm{CH}_{\text {Fluoren }}\right), 120.0\left(2 \times \mathrm{CH}_{\text {Fluoren }}\right), 74.2\left(\underline{\mathrm{C}}\left(\mathrm{CH}_{3}\right)_{3}\right), 67.0\left(\mathrm{COO} \mathrm{H}_{2}\right), 61.9\left(\mathrm{OCH}_{2}\right), 54.6$ $(\mathrm{CH}), 47.2\left(\mathrm{CH}_{\text {Fluoren }}\right), 43.6\left(\underline{\mathrm{CH}}_{2} \mathrm{Ph}\right), 27.4\left(\mathrm{C}\left(\underline{\mathrm{CH}}_{3}\right)_{3}\right)$; ESI-MS: calculated for $\left[\mathrm{C}_{29} \mathrm{H}_{32} \mathrm{~N}_{2} \mathrm{O}_{4}+\mathrm{H}\right]^{+}\left(\mathrm{M}+\mathrm{H}^{+}\right) 473.24$, obtained 473.28; m.p. $=125-130{ }^{\circ} \mathrm{C} ;[\alpha]_{\mathrm{D}}{ }^{2{ }^{\circ} \mathrm{C}}=$ $+25.0\left(\right.$ c $\left.1, \mathrm{CHCl}_{3}\right)$.

(9H-fluoren-9-yl)methyl ((S)-3-(tert-butoxy)-1-oxo-1-(((S)-1-phenylethyl)amino)propan2-yl)carbamate (6): ${ }^{1} \mathrm{H}$ NMR $\left(400 \mathrm{MHz}, \mathrm{CDCl}_{3}\right): \delta=7.78\left(\mathrm{~d}, J=7.5 \mathrm{~Hz}, 2 \mathrm{H}, \mathrm{H}_{\mathrm{ar}-}\right.$ Fluoren), 7.61 (d, $\left.J=7.4 \mathrm{~Hz}, 2 \mathrm{H}, \mathrm{H}_{\text {ar-Fluoren }}\right), 7.29-7.45$ (m, 9H $\mathrm{ar}$ ), 7.03 (bs, 1H, NH), 5.83

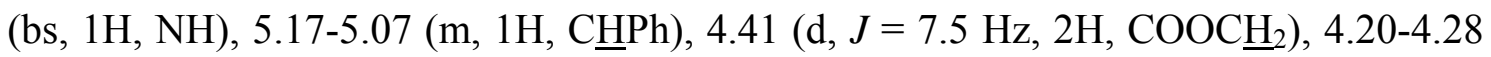
$\left(\mathrm{m}, 2 \mathrm{H}, \mathrm{COCH}+\mathrm{CH}_{\text {Fluoren }}\right), 3.81\left(\mathrm{dd}, J=8.5,4.1 \mathrm{~Hz}, 1 \mathrm{H}, \mathrm{OCH}_{\mathrm{a}} \mathrm{CH}_{\mathrm{b}}\right), 3.32(\mathrm{t}, J=8.2$ $\left.\mathrm{Hz}, 1 \mathrm{H}, \mathrm{OCH}_{\mathrm{a}} \underline{\mathrm{C}}_{\mathrm{b}}\right), 1.53\left(\mathrm{~d}, J=6.9 \mathrm{~Hz}, 3 \mathrm{H}, \mathrm{CH}_{3}\right), 1.15\left(\mathrm{~s}, 9 \mathrm{H}, \mathrm{C}\left(\mathrm{CH}_{3}\right)_{3}\right) ;{ }^{13} \mathrm{C} \mathrm{NMR}$ 
$\left(100 \mathrm{MHz}, \mathrm{CDCl}_{3}\right): \delta=169.2(\mathrm{COO}), 156.0(\mathrm{HNCOO}), 143.9\left(\mathrm{C}_{\text {ipso }} \mathrm{Ph}\right), 143.7(2 \times$ $\left.\mathrm{C}_{\text {Fluoren }}\right), 141.3\left(2 \times \mathrm{C}_{\text {Fluoren }}\right), 128.7\left(2 \times \mathrm{C}_{\text {meta Ph }}\right), 127.7\left(2 \times \mathrm{CH}_{\text {Fluoren }}\right), 127.4\left(\mathrm{C}_{\text {para Ph }}\right)$, $127.1\left(2 \times \mathrm{CH}_{\text {Fluoren }}\right), 126.1\left(2 \times \mathrm{C}_{\text {ortho }} \mathrm{Ph}\right), 125.1\left(2 \times \mathrm{CH}_{\text {Fluoren }}\right), 120.0\left(2 \times \mathrm{CH}_{\text {Fluoren }}\right)$, $74.3\left(\underline{\mathrm{C}}\left(\mathrm{CH}_{3}\right)_{3}\right), 67.0\left(\mathrm{COOC}_{2}\right), 61.8\left(\mathrm{OCH}_{2}\right), 54.0(\mathrm{CH}), 49.2\left(\underline{\left.\mathrm{CHCH}_{3}\right),} 47.1\right.$ $\left(\mathrm{CH}_{\text {Fluoren }}\right), 27.3\left(\mathrm{C}\left(\underline{\mathrm{CH}}_{3}\right)_{3}\right), 22.0\left(\mathrm{CHCH}_{3}\right)$; calculated for $\left[\mathrm{C}_{30} \mathrm{H}_{34} \mathrm{~N}_{2} \mathrm{O}_{4}+\mathrm{H}\right]^{+}\left(\mathrm{M}+\mathrm{H}^{+}\right)$ 487.25, obtained 487.26; wax; $[\alpha]_{\mathrm{D}}^{24^{\circ} \mathrm{C}}=-2.9\left(\mathrm{c} 1, \mathrm{CHCl}_{3}\right)$.

(9H-fluoren-9-yl)methyl ((S)-3-(tert-butoxy)-1-oxo-1-(((R)-1phenylethyl)amino)propan-2-yl)carbamate (7): ${ }^{1} \mathrm{H}$ NMR (400 $\left.\mathrm{MHz}, \mathrm{CDCl}_{3}\right)$ : $\delta=7.78\left(\mathrm{~d}, J=7.5 \mathrm{~Hz}, 2 \mathrm{H}, \mathrm{H}_{\text {ar-Fluoren }}\right), 7.61$ (d, $\left.J=7.5 \mathrm{~Hz}, 2 \mathrm{H}, \mathrm{H}_{\text {ar-Fluoren }}\right), 7.28-7.45$ (m, $9 \mathrm{H}_{\mathrm{ar}}$ ), 6.96 (bs, $\left.1 \mathrm{H}, \mathrm{NH}\right), 5.80$ (bs, 1H, NH), 5.20-5.09 (m, 1H, CㅂPh), 4.43 (d, J=6.9 $\left.\mathrm{Hz}, 2 \mathrm{H}, \mathrm{COOC}_{2}\right), 4.24\left(\mathrm{~m}, 2 \mathrm{H}, \mathrm{COCH}+\mathrm{CH}_{\text {Fluoren }}\right), 3.86(\mathrm{dd}, J=8.1,3.4 \mathrm{~Hz}, 1 \mathrm{H}$, $\left.\mathrm{OCH}_{\mathrm{a}} \mathrm{CH}_{\mathrm{b}}\right), 3.41\left(\mathrm{t}, J=8.2 \mathrm{~Hz}, 1 \mathrm{H}, \mathrm{OCH}_{\mathrm{a}} \underline{\mathrm{CH}}_{\mathrm{b}}\right), 1.52\left(\mathrm{~d}, J=6.9 \mathrm{~Hz}, 3 \mathrm{H}, \mathrm{CH}_{3}\right), 1.23(\mathrm{~s}$, 9H, $\left.\mathrm{C}\left(\mathrm{CH}_{3}\right)_{3}\right) ;{ }^{13} \mathrm{C} \mathrm{NMR}\left(100 \mathrm{MHz}, \mathrm{CDCl}_{3}\right): \delta=169.3$ (COO), 156.0 (HNCOO), 143.9 and $143.7\left(2 \times \mathrm{C}_{\text {Fluoren }}\right), 143.0\left(\mathrm{C}_{\text {ipso Ph }}\right), 141.3\left(2 \times \mathrm{C}_{\text {Fluoren }}\right), 128.7\left(2 \times \mathrm{C}_{\text {meta } \mathrm{Ph}}\right), 127.7(2$ $\left.\times \mathrm{CH}_{\text {Fluoren }}\right), 127.4\left(\mathrm{C}_{\text {para Ph }}\right), 127.1\left(2 \times \mathrm{CH}_{\text {Fluoren }}\right), 126.0\left(2 \times \mathrm{C}_{\text {ortho }} \mathrm{Ph}\right), 125.1(2 \times$ $\left.\mathrm{CH}_{\text {Fluoren }}\right), 120.0\left(2 \times \mathrm{CH}_{\text {Fluoren }}\right), 74.3\left(\underline{\mathrm{C}}\left(\mathrm{CH}_{3}\right)_{3}\right), 67.1\left(\mathrm{COO} \mathrm{CH}_{2}\right), 62.0\left(\mathrm{OCH}_{2}\right), 54.4$ $(\mathrm{CH}), 49.0\left(\underline{\mathrm{CHCH}}_{3}\right), 47.2\left(\mathrm{CH}_{\text {Fluoren }}\right), 27.5\left(\mathrm{C}\left(\underline{\mathrm{CH}}_{3}\right)_{3}\right), 22.1\left(\mathrm{CH}^{2} \mathrm{H}_{3}\right)$; calculated for $\left[\mathrm{C}_{30} \mathrm{H}_{34} \mathrm{~N}_{2} \mathrm{O}_{4}+\mathrm{H}\right]^{+}\left(\mathrm{M}+\mathrm{H}^{+}\right) 487.25$, obtained 487.26; m.p. $=147-148{ }^{\circ} \mathrm{C} ;[\alpha]_{\mathrm{D}}{ }^{2{ }^{\circ} \mathrm{C}}=$ $+48.7\left(\right.$ c $\left.1, \mathrm{CHCl}_{3}\right)$.

Serines $(10,11)$ : Piperidine (2 eq.) was added to a solution of serines $6 / 7$ in anhydrous DMF $(5 \mathrm{ml})$. The mixture was left to react for $2 \mathrm{~h}$ at room temperature, under argon atmosphere. After water $(10 \mathrm{ml})$ and dichloromethane $(10 \mathrm{ml})$ addition to the mixture, the phases were separated. The aqueous phase was extracted with dichloromethane $(3 \times$ $10 \mathrm{ml}$ ) and the organic phases washed with brine. After evaporation of the volatiles at reduced pressure, the mixture was purified by chromatographic column (eluent: Hexane/AcOEt 1:1), affording serines 10/11 with $100 \%$ yield.

(S)-2-amino-3-(tert-butoxy)- $N$-((S)-1-phenylethyl)propanamide (10): ${ }^{1} \mathrm{H}$ NMR (400 $\left.\left.\mathrm{MHz}_{\mathrm{CDCl}}\right)\right): \delta=7.65(\mathrm{~d}, J=7.2 \mathrm{~Hz}, 1 \mathrm{H}, \mathrm{NH}), 7.33-7.39\left(\mathrm{~m}, 4 \mathrm{H}_{\mathrm{ar}}\right), 7.25-7.31(\mathrm{~m}, 1$ $\mathrm{H}_{\text {para }}$ ), 5.13 (dt, 15.0, $\left.6.9 \mathrm{~Hz}, 1 \mathrm{H}, \mathrm{C} \underline{\mathrm{HPh}}\right), 3.62$ (dd, $J=11.4,8.1 \mathrm{~Hz}, 1 \mathrm{H}, \mathrm{NH}_{2} \mathrm{C} \underline{\mathrm{H}}$ ), 3.48-3.54 (m, $2 \mathrm{H}, \mathrm{OCH}_{2}$ ), 1.83 (bs, $2 \mathrm{H}, \mathrm{NH}_{2}$ ), 1.51 (d, J=6.9 Hz, $3 \mathrm{H}, \mathrm{CH}_{3}$ ), 1.19 (s, $\left.9 \mathrm{H}, \mathrm{C}\left(\mathrm{CH}_{3}\right)_{3}\right)$;

(S)-2-amino-3-(tert-butoxy)- $N-\left((R)-1\right.$-phenylethyl)propanamide (11): ${ }^{1} \mathrm{H}$ NMR (400 $\mathrm{MHz}_{\mathrm{CDCl}}$ ): $\delta=7.72(\mathrm{~d}, J=7.8 \mathrm{~Hz}, 1 \mathrm{H}, \mathrm{NH}), 7.31-7.37\left(\mathrm{~m}, 4 \mathrm{H}_{\mathrm{ar}}\right), 7.22-7.28(\mathrm{~m}, 1$ $\mathrm{H}_{\text {para }}$ ), 5.12 (dt, 15.0, 7.0 Hz, 1 H, C파), 3.50-3.63 (m, $\left.3 \mathrm{H}, \mathrm{OCH}_{2} \mathrm{CH}\right), 2.06$ (bs, $2 \mathrm{H}$, $\left.\mathrm{NH}_{2}\right), 1.51\left(\mathrm{~d}, J=6.9 \mathrm{~Hz}, 3 \mathrm{H}, \mathrm{CH}_{3}\right), 1.19\left(\mathrm{~s}, 9 \mathrm{H}, \mathrm{C}\left(\mathrm{CH}_{3}\right)_{3}\right)$;

Ethoxysilylated serines $(\mathbf{1 2}, \mathbf{1 3}, \mathbf{1 4})$ : To a solution of serine 8/10/11 in anhydrous dichloromethane, 1 eq. of 3-(triethylsilyl)propyl isocyanate was added dropwise. The reaction was left with stirring overnight at reflux under argon atmosphere. The solvent was evaporated at reduced pressure and the residue was purified by chromatographic column (eluent: dichloromethane), affording serines 14/12/13 with 98\%, 90\% and 90\% yields, respectively. 
$\mathrm{N}$-(((S)-3-(tert-butoxy)-1-oxo-1-(((S)-1-phenylethyl)amino)propan-2-yl)carbamoyl)-4(triethoxysilyl)butanamide (12): ${ }^{1} \mathrm{H} \mathrm{NMR}\left(400 \mathrm{MHz}, \mathrm{CDCl}_{3}\right): \delta=7.31-7.36\left(\mathrm{~m}, 4 \mathrm{H}_{\mathrm{ar}}\right.$ ), 7.25-7.27 (m, $1 \mathrm{H}_{\text {para }}$ ), 7.18 (d, $\left.J=7.7 \mathrm{~Hz}, 1 \mathrm{H}, \mathrm{NH}\right), 5.55$ (d, $\left.J=6.0 \mathrm{~Hz}, 1 \mathrm{H}, \mathrm{NH}\right)$, 5.07 (m, $1 \mathrm{H}, \mathrm{NHC} \underline{\mathrm{H}}), 4.96-5.02(\mathrm{~m}, 1 \mathrm{H}, \mathrm{NH}), 4.34(\mathrm{ddd}, J=8.9,5.9,4.3 \mathrm{~Hz}, 1 \mathrm{H}$, $\mathrm{CHPh}), 3.83\left(\mathrm{q}, J=7.0 \mathrm{~Hz}, 6 \mathrm{H}, 3 \times \mathrm{SiOCH}_{2}\right), 3.78(\mathrm{dd}, J=8.5,4.3 \mathrm{~Hz}, 1 \mathrm{H}$, $\left.\mathrm{OCH}_{\mathrm{a}} \mathrm{CH}_{\mathrm{b}}\right), 3.28\left(\mathrm{t}, J=8.6 \mathrm{~Hz}, 1 \mathrm{H}, \mathrm{OCH}_{\mathrm{a}} \underline{\mathrm{H}}_{\mathrm{b}}\right), 3.12-3.20\left(\mathrm{~m}, 2 \mathrm{H}, \mathrm{OCH}_{2}\right), 1.56-1.66$ $\left(\mathrm{m}, 2 \mathrm{H}, \mathrm{CH}_{2} \underline{\mathrm{C}}_{2} \mathrm{CH}_{2}\right), 1.50\left(\mathrm{~d}, J=6.9 \mathrm{~Hz}, 3 \mathrm{H}, \mathrm{CH}_{3}\right), 1.24(\mathrm{t}, J=7.0 \mathrm{~Hz}, 9 \mathrm{H}, 3 \times$ $\left.\mathrm{OCH}_{2} \underline{\mathrm{C}}_{3}\right), 1.13$ (s, $\left.9 \mathrm{H}, \mathrm{C}\left(\mathrm{CH}_{3}\right)_{3}\right), 0.61-0.61$ (m, $\left.2 \mathrm{H}, \mathrm{SiCH}_{2}\right)$;

$\mathrm{N}$-(((S)-3-(tert-butoxy)-1-oxo-1-(((R)-1-phenylethyl)amino)propan-2-yl)carbamoyl)-4(triethoxysilyl)butanamide (13): ${ }^{1} \mathrm{H} \mathrm{NMR}\left(400 \mathrm{MHz}, \mathrm{CDCl}_{3}\right): \delta=7.18-7.35(\mathrm{~m}, 6 \mathrm{H}$, $\left.\mathrm{NH}+\mathrm{H}_{\mathrm{ar}}\right), 5.68(\mathrm{~d}, J=6.3 \mathrm{~Hz}, 1 \mathrm{H}, \mathrm{NH}), 5.25(\mathrm{t}, J=5.6 \mathrm{~Hz}, 1 \mathrm{H}, \mathrm{NH}), 5.06(\mathrm{~m}, 1 \mathrm{H}$, $\mathrm{NHC} \underline{\mathrm{H}}$ ), 4.35 (ddd, $J=8.3,6.3,4.2 \mathrm{~Hz}, 1 \mathrm{H}, \mathrm{CHPh}), 3.81$ (q, $J=7.0 \mathrm{~Hz}, 6 \mathrm{H}, 3 \times$ $\left.\mathrm{SiOCH}_{2}\right), 3.78-3.84\left(\mathrm{~m}, 1 \mathrm{H}, \mathrm{OC}_{\mathrm{a}} \mathrm{CH}_{\mathrm{b}}\right), 3.36\left(\mathrm{t}, J=8.4 \mathrm{~Hz}, 1 \mathrm{H}, \mathrm{OCH}_{\mathrm{a}} \underline{\mathrm{H}}_{\mathrm{b}}\right), 3.11$ (ddd, $\left.J=13.1,7.1,2.1 \mathrm{~Hz}, 2 \mathrm{H}, \mathrm{OCH}_{2}\right), 1.53-1.62\left(\mathrm{~m}, 2 \mathrm{H}, \mathrm{CH}_{2} \mathrm{CH}_{2} \mathrm{CH}_{2}\right), 1.48(\mathrm{~d}, J=$

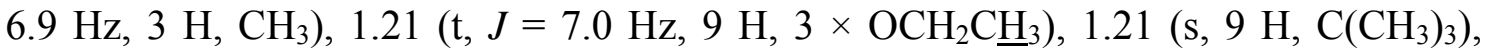
0.57-0.64 (m, $\left.2 \mathrm{H}, \mathrm{SiCH}_{2}\right)$;

(S)-methyl 12-(tert-butoxymethyl)-4,4-diethoxy-8,10-dioxo-3-oxa-9,11-diaza-4silatridecan-13-oate (14): ${ }^{1} \mathrm{H} \mathrm{NMR}\left(400 \mathrm{MHz}, \mathrm{CDCl}_{3}\right): \delta=5.28(\mathrm{~d}, J=8.6 \mathrm{~Hz}, 1 \mathrm{H}$, $\mathrm{NH}), 4.96(\mathrm{t}, J=5.5 \mathrm{~Hz}, 1 \mathrm{H}, \mathrm{NH}), 4.58(\mathrm{dt}, J=8.6,3.2 \mathrm{~Hz}, 1 \mathrm{H}, \mathrm{CH}), 3.81$ (q, $J=7.0$ $\left.\mathrm{Hz}, 6 \mathrm{H}, 3 \times \mathrm{SiOCH}_{2}\right), 3.78\left(\mathrm{dd}, J=9.0,3.2 \mathrm{~Hz}, 1 \mathrm{H}, \mathrm{OCH}_{\mathrm{a}} \mathrm{CH}_{\mathrm{b}}\right), 3.72\left(\mathrm{~s}, 3 \mathrm{H}, \mathrm{OCH}_{3}\right)$, $3.56\left(\mathrm{dd}, J=9.0,3.2 \mathrm{~Hz}, 1 \mathrm{H}, \mathrm{OCH}_{\mathrm{a}} \underline{\mathrm{CH}}_{\mathrm{b}}\right), 3.10-3.25\left(\mathrm{~m}, 2 \mathrm{H}, \mathrm{COCH}_{2}\right), 1.57-1.66(\mathrm{~m}, 2$ $\left.\mathrm{H}, \mathrm{CH}_{2} \mathrm{CH}_{2} \mathrm{CH}_{2}\right), 1.22\left(\mathrm{t}, J=7.0 \mathrm{~Hz}, 9 \mathrm{H}, 3 \times \mathrm{OCH}_{2} \underline{\mathrm{C}}_{3}\right), 1.13\left(\mathrm{~s}, 9 \mathrm{H}, \mathrm{C}\left(\mathrm{CH}_{3}\right)_{3}\right), 0.60-$ $0.68\left(\mathrm{~m}, 2 \mathrm{H}, \mathrm{SiCH}_{2}\right) ;{ }^{13} \mathrm{C} \mathrm{NMR}\left(100 \mathrm{MHz}, \mathrm{CDCl}_{3}\right): \delta=173.2(\mathrm{CH}(\underline{\mathrm{CO}}) \mathrm{O}+$ $\left.\mathrm{CH}_{2}(\underline{\mathrm{CO}}) \mathrm{NH}\right), 158.6(\mathrm{NHCONH}), 74.2\left(\underline{\mathrm{C}}\left(\mathrm{CH}_{3}\right)_{3}\right), 63.6\left(\mathrm{OCH}_{2}\right), 59.3\left(3 \times \mathrm{SiOCH}_{2}\right)$, $54.8(\mathrm{CH}), \quad 53.1 \quad\left(\mathrm{OCH}_{3}\right), 43.9\left(\mathrm{COCH}_{2}\right), 28.2\left(\mathrm{C}_{\left.\left(\mathrm{CH}_{3}\right)_{3}\right),} 24.3\left(\mathrm{SiCH}_{2}\right), 19.2\right.$ $\left(\mathrm{OC}_{2} \mathrm{CH}_{3}\right), 8.6\left(\mathrm{CH}_{2} \underline{\mathrm{CH}}_{2} \mathrm{CH}_{2}\right)$;

\section{Acknowledgements}

The authors thank to Fundação para a Ciência e a Tecnologia (FCT) for financial support and COMPETE through grant no. PEst-C/EQB/LA0006/2011. C. A. D. Sousa thanks the grant SFRH / BPD / 80100 / 2011.

\section{References}

[1] Jacobsen, E. N.; Pfaltz, A.; Yamamoto, H., Eds. Comprehensive Asymmetric Catalysis I-III, Chapter 33.1- Diels-Alder Reactions; Springer-Verlag: Berlin, 1999.

[2] Nicolaou, K. C.; Snyder, S. A.; Montagnon, T.; Vassilikogiannakis, G. Angewandte Chemie International Edition 2002, 41, 1668-1698.

[3] Maruoka, K.; Conception, A. B. Bull Chem Soc Jpn 1992, 65, 3501-3503.

[4] Corey, E. J. Angew Chem Int Ed 2002, 41, 1650-1667.

[5] Kesharwani, M. K.; Ganguly, B. Croat Chem Acta 2009, 82, 291-298.

[6] Fringuelli, F.; Piermatti, O.; Pizzo, F.; Vaccaro, L. Eur J Org Chem 2001, 439455. 
[7] Vidiš, A.; Ohlin, C. A.; Laurenczy, G.; Küsters, E.; Sedelmeier, G.; Dyson, P. J. Advanced Synthesis \& Catalysis 2005, 347, 266-274.

[8] Maruoka, K.; Concepcion, A. B.; Yamamoto, H. Bull Chem Soc Japan 1992, 65, 3501-3503.

[9] Whitesell, J. K.; Bhattacharya, A. K.; Henke, K. J Chem Soc, Chem Commun 1982, 988-989.

[10] Whitesell, J. K.; Liu, C. L.; Buchanan, C. M.; Chen, H.-H.; Minton, M. A. J Org Chem 1986, 51, 551-553.

[11] Parlar, H.; Baumann, R. Angewandte Chemie International Edition in English 1981, 20, 1014-1014.

[12] Mamedov, E. Russian Journal of Applied Chemistry 2006, 79, 1621-1625.

[13] Cativiela, C.; Fraile, J. M.; Garcia, J. I.; Mayoral, J. A.; Figueras, F.; De Menorval, L. C.; Alonso, P. J. Journal of Catalysis 1992, 137, 394-407.

[14] Hondrogiannis, G.; Pagni, R. M.; Kabalka, G. W.; Kurt, R.; Cox, D. Tetrahedron Letters 1991, 32, 2303-2306.

[15] Hashimoto, S.; Komeshima, N.; Koga, K. J Chem Soc, Chem Comm 1979, 437438 .

[16] Evans, D. A.; Miller, S. J.; Lectka, T.; von Matt, P. J Am Chem Soc 1999, 121, 7559-7573.

[17] Sousa, C. A. D.; Vale, M. L. C.; Rodríguez-Borges, J. E.; García-Mera, X.; Rodríguez-Otero, J. Tetrahedron Letters 2008, 49, 5777-5781.

[18] Sousa, C. A. D.; Vale, M. L. C.; García-Mera, X.; Rodríguez-Borges, J. E. Tetrahedron 2012, 68, 1682-1687.

[19] Bottari, E.; Festa, M. R.; Jasionowska, R. Journal of Coordination Chemistry 1988, 17, 245-253.

[20] Bodkhe, A. S.; Patil, S. S.; Shaikh, M. M. Acta Poloniae Pharmaceutica - Drug Research 2012, 69, 871-877.

[21] Teo, Y.-C.; Chua, G.-L. Tetrahedron Letters 2008, 49, 4235-4238.

[22] Hager, M.; Wittmann, S.; Schätz, A.; Pein, F.; Kreitmeier, P.; Reiser, O. Tetrahedron: Asymmetry 2010, 21, 1194-1198. 